\title{
Classroom Dialogues and Reflections in Southeast Asia inspired by Grundtvig's educational Ideas ${ }^{1}$
}

\author{
By Hanne Luplau Kjer Hansen
}

"Grundtvig is a figure whose time has come." (Steven Borish 1996)

The purposes of the present essay are manyfold.

Firstly, I would like to present some classroom dialogues on N. F. S. Grundtvig's educational ideas, as they took place in a multicultural classroom at a university in Southeast Asia, Asian Institute of Technology (AIT). ${ }^{3}$

Secondly, it is my intention to demonstrate how some of Grundtvig's key concepts, such as mother tongue [modersmål], the historical-poetical [det historisk-poetiske], the living word [det levende ord], true interaction [sand veksel-virkning], the 'folkelige', life-enlightenment [livs-oplysning $]^{4}$ were understood by the students of that classroom.

Thirdly, I want to argue the actuality and yet timelessness of Grundtvig's ideas and of his positions on "cultivation and capability, and learnedness" [Dannelse \& Duelighed og Lærdom], primarily as they are discussed by himself in Nordens Mytologi (NM) ${ }^{5}$ [Norse Mythology], and as I have found them to emerge from his many songs. ${ }^{6}$ Another source is his petition to the Danish king for a folk-university in Sorø, in $\mathrm{Om}$ Indretningen af Soro Academi til en folkelig Hoiskole (1843) [On the Conversion of Soro Academy into a folk-university]. ${ }^{7}$

Next, I proceed to discuss Grundtvig's positions in comparison with the ideas of German and British educational and sociological philosophers, as Grundtvig was inspired by traditions of these countries. American ideas are also included, as they were part of the course reading materials, and as such the philosophical ground for the discourse together with the British materials.

The form of this essay is to some extent that of what we may call a field research report, indicating the methodology to be qualitative ${ }^{8}$ (anthropological and hermeneutic-critical) and participatory, meaning the researcher is 'on location' and working together with the persons involved, rather than studying them. In this way the researcher becomes part of the research process.

Instead of speaking of methodology, the concept of approach is usually applied in cases of qualitative research. This point will briefly be discussed against Grundtvig's attitude to methodology and anthropology. 
Finally, it should be stressed that Grundtvig's educational ideas have been applied to illuminate the present study, in a manner consistent with an approach of qualitative and participatory research, rather than to constitute a Grundtvig-study in itself.

So, the question I pose is: How may Grundtvig's ideas be an inspiration to university education in Southeast Asian cultures and contexts and help spur educational development?

\section{The classroom}

"what they all can do, and are willing to do, is: to open everything up to challenge",

They, the students, were sitting there - in a classroom at a university in Thailand $^{10}$ - sixteen in number from various schools and programmes, coming from ten different countries. They represented ten different national languages and even more mother tongues together with each their specific variety of the common foreign language, English ("Englishes" as my American colleague would name it). As to religion and philosophy, and thus their conceptualisation of learning and society, they offered a virtual rainbow of challenges to our educational journey.

We, the teachers, were standing there in the same room, the two of us, one from America and one from Denmark. We, too, had our particular mother tongue, and I had my special variety of English.

Together we made up a learning community.

The occasion of our assembly was a course on curriculum development, applied educational theories so to speak, supplementary to the students' academic careers and contributing to their future services in their home countries.

In addition to that, the course would serve as training in English as Second Language and English for Specific Purposes.

That day was special in that Grundtvig was on the agenda. Our intention was partly to present the man and his ideas together with the national and historical context, partly to create a dialogue on the idea of cultivation [dannelse] and capability [duelighed] and again relate this twofold concept to the third concept of Grundtvig's learnedness [lærdom]. As signposts I had chosen what I believe to be the basic pillars of Grundtvig's educational ideas, the historical-poetical [det historiskpoetiske]; mother tongue [modersmål]; mutual teaching and learning [sand indbyrdes undervisning]; living interaction [levende veksel- 
virkning]; the living word [det levende ord]; the life and culture of the people [folkelighed]. - Incidentally, my colleage and I decided to translate the term 'folkelig' as folk-alike, which my colleague, a professor in American and English languages, concidered linguistically appropriate and meaningful to the students.

Before discussing content and dialogues I consider it convenient to submit a further presentation of the participants and the overall philosophy of the course.

\section{The students}

Taking the May 1997 batch of students as an example, the participants may be presented by their home countries as follows: China, Nepal, Mongolia, Cambodia, Vietnam, Laos, Kyrgizstan, Indonesia, Sri Lanka, and Thailand. As far as their study programmes are concerned, they were equally different: Agriculture, Computer Science, Urban Planning, Industrial Technology, Business Management and Marketing, and in addition to those Human Resources and Gender Development Studies. This naturally offered a unique opportunity to obtain cross-disciplinary insight.

\section{The course}

"Then one shall tell the difference between sunshine and lightning (...) For as it goes without saying, one light revives, the other one kills",II

Some of its basic educational ideas are - in post-modern terms 'autonomy' and 'ownership'. This means that the students are expected to engage actively in the creative learning processes, expressed through classroom discussions, group work with paper presentation and roundtable discussions. So no teacher was standing tall preaching, and no student had to learn by rote.

In this way we endeavoured to create a free room of conversation in an atmosphere of mutual trust and sincerity, what may be referred to in the well known Habermas inspired term as a non-coercive dialogue, and which may lead to communicative action according to the German sociologist and philosopher Jürgen Habermas; ${ }^{12}$ in other words, a critical discourse which leads to genuine knowledge and insight.

An echo of Grundtvig's educational ideas may be recognized here in his manner of addressing his students as "mine Herrer" [Gentlemen] and 
in his aim to establish a 'levende veksel-virkning' [living inter-action] and true enlightenment: "like sunshine is to the black mould, so is true enlightenment to the kin of mould." 13

\section{The approach}

"Cultivation and capability must always be intended for the life of the people in the moment,

Whereas learnedness is for human life in its full sense",I

To clarify both my own studies and my participation in the course, I had chosen Grundtvig's idea of 'Dannelse og Duelighed' [cultivation and capability) and 'Lærdom' [learnedness] as an approach to curriculum development and cultural changes.

The term 'cultivation' is deliberately chosen to describe the core meaning of the Grundtvig term 'Dannelse', a concept which in English literature often is seen referred to as 'Liberal Education' (e.g. R. S. Peters 1977). ${ }^{15}$ Likewise, 'capability' is chosen to describe the term 'Duelighed', instead of 'qualification' to indicate 'coping with'. This may be justified by referring to the above Grundtvig-quotation and his argumentation of the same in dialogue with the term 'Lærdom'. This concept I have translated as 'learnedness' in parallel with the phrase 'learned people'. Grundtvig's concern was that the two same categories should inevitably meet to avoid an "overfladelig Politur" [superficial polish] of the learners, whereas 'Lærdom' [learnedness] should always meet with real life to avoid the 'school-masters getting onto a false track', meaning both parties should learn from one another.

In their essence, Grundtvig's educational ideas may be applied as an anthropological approach to curriculum development and research. Since Grundtvig's preoccupation was both the everyday life of the people and human life in general, an approach from his ideas may manifest itself as a qualitative and participatory research ${ }^{16}$ of the idea of 'curriculum' as both intention, reality and philosophy, in that 'curriculum' constitutes a research field by itself.

Naturally, one may always argue the application of Grundtvig's educational ideas as an anthropological approach to be contradictory, in that he possibly would have been opposed to this idea. Bugge (1965, $335)^{17}$ claims that Grundtvig's critical attitude to the philanthropists was based on their fascination with methodology, because he was alarmed by their methodological deduction and anthropological premises. 
The qualitative approach applied in the present study - relating to Wilhelm Dilthey's (see below) historical-critical and hermeneutic anthropological view, including religion as 'one great cultural system' as well as Grundtvig's personal Christian life-understanding, composed into an interactive whole with due respect to the 'folkelige' - may after all accommodate Grundtvig's critique.

\section{Anthropology and methodology}

Anthropology as a critical-historical and hermeneutic method is known in European tradition from Wilhelm Dilthey ${ }^{18}$ (1833-1911), and through him this was introduced in the USA where, according to R. C. Bogdan and S. K. Biklen, ${ }^{19}$ Franz Boas in 1898 "became the first scientist to take up at university level the field of Anthropology". From this inspiration, John Dewey (1859-1952) shaped his 'learning by doing' concept, reflecting a positivist and rationalist philosophy, different from Dilthey's philosophical term 'understanding'.

To revert to Dilthey, human beings cannot understand themselves from the interior - through introspection - but rather from expression, i.e. through the cultural objectives, in the way they are present in mankind's great cultural systems, such as religion, art, science, politics, laws, and hence, I suggest, in education. In the British ethnographer Bronislaw Malinowski's (1884-1942) wording that is "to grasp the native's point of view", analogous to what Grundtvig terms the 'folkelige'.

Dilthey asserts religion to be one "great cultural system" through which mankind's hopes, dreams and actions emerge, akin to Grundtvig's views of "Menneske først, Kristen saa" [Man first, then (and thus) a Christian]. I interpret Grundtvig's dictum to mean that in coming to terms with oneself as a true human being then one may become a Christian in the same true way and thus become a true Christian, human being.

Reidar Myhre ${ }^{20}$ similarly argues that "in Europe, after the Second World War, a dialogue between educationalists and theologians came into being", a dialogue which allegedly emphasized involvement of values, life understanding and the concept of Man, in a comprehensive consideration of education. These ideas sound very familiar in our days. Grundtvig's age was a 'moving time' [en bevæget Tid], as Grundtvig ${ }^{21}$ characterized it, using an image indicating both a physical and a spiritual movement, like "rivers that run out into the great ocean". ${ }^{22}$ Again we come close to our new millennium.

Since anthropology deals with cultural change, and since Grundtvig 
never concealed that Christianity was the foundation for his educational ideas, it seems natural to me to take up the question of religion as one cultural factor to have an impact on educational ideas and positions.

Another urgent cultural factor is language; therefore, the issue of the mother tongue versus foreign language acquisition and identity may be encompassed by Grundtvig's 'framework'.

In comparing Grundtvig's notions with the ideas of curriculum of our century, Peters' (1974) distinction between two categories of 'knowledge' seems relevant to the present approach, viz. those of "knowledge for the mind" and "knowledge for reality", the latter provided for by education, in a reciprocal way. Grundtvig, apparently, goes a step further in recognizing 'reality' as two interactive 'lives', human life in general and actual life in particular.

Consequently, both 'knowledge for the mind' and 'knowledge for reality' may be embedded in his two-fold concept: 'cultivation and capability', reflecting the 'folk-life of the moment', while Peters' (1974; 1977a) third category, "knowledge for its own sake", comes close to 'learnedness', reflecting 'human life in general'. This latter kind of knowledge should not, in Grundtvig's opinion, be in the possession of the 'multitude', since this would merely lead to the corruption of both knowledge and the learner. He may have been pointing to the so-called Encyclopaedic School, to which at first he erroneously believed Rousseau belonged, as well as to the Philantropist School (in Dessau) including Basedow and Pestalozzi, ${ }^{23}$ whose ideas I have discussed elsewhere. ${ }^{24}$ Grundtvig's elaboration of the issue may be cited as follows:

"the latest prevailing self-knowledge (...) that insisted that he who wanted to be wiser than Peer Jensen was already mad or fast on his way to become so; that was, one will realize, in its essence arch-ignorance "25

This is obviously a hint to the ancient Greek virtues of self-knowledge and self-control (Aristotle), virtues which he finds have been ignored for a long time in favour of 'The Roman Yoke', which is why he suggests an "awakening in the North", including England, in order to enter into a new era, founded on Nordic values.

Peters $(1977 \mathrm{~b}, 123)$ makes the following analogous reference, in connection with Plato's idea that human potential is unevenly distributed:

"something that people seem to get very hot under the collar about nowadays in the Jensen Controversy" 26 
It may be concluded then that a curriculum for all people should be shared by each and everyone in their exchange of experience and knowledge, reflected against their cultural heritage, i.e. mutual teaching and learning and life enlightenment in Grundtvigian terms and an interactive, participatory process, to phrase it in contemporary words, or, as it has been called, participant research (H. F. Wolcott, 1995), ${ }^{27}$ i.e. included in the curriculum.

As one consequence I let Grundtvig's voice, as it inspired me through his songs, into my studies, and allowed it to be heard in the present study, and I invited his dialogue from Norse Mythology to challenge my reflections on what he called Sindbilled-Sprog ${ }^{28}$ [language of imagery]. A final point to be made in this place may be that both Grundtvig and the Humanists were/are culture critical in their basic attitudes towards The Establishment.

Back to the classroom: a session on Danish educational ideas and on N. F. S. Grundtvig

To broaden the scope of the discussion on different approaches, curriculum traditions and cultural changes, we arranged a special interlude with Grundtvig and Danish traditions. As an introduction to the group work the students were given a short lecture on the historical and cultural background for these ideas, highlighting some historical facts and events that led to his visions. Next the students were asked to discuss in groups and to present in plenum what they would understand by the five concepts, historical-poetical; mother tongue; interaction; living word; folk-alike [folkelig]; life enlightenment, and then consider their own national history in the light of these concepts.

On the 'historical-poetical' dimension a student commented that: "today is history tomorrow". This may be a little slogan-like; however, it is very illustrative of the rapid changes in the world, and perhaps inspired another student's subtle remark that the 'version' of history depends on the context and the situation: "For example, when we had British rule, we had British education", reminding us that colonial periods and their educational history is also part of a nation's history.

A couple of students from Vietnam and Indonesia were lamenting that "history in university is not useful for business students once we have graduated, so why put history into the curriculum?", as was the case in 
their countries. We suggested they considered history from two perspectives, deadlock or ballast, meaning that history can prevent development or provide progress, depending on the way we use it. This also would apply with their business careers so as to negotiate with a clientèle from foreign nations and cultures on the grounds of knowing one's own history.

Another Vietnamese student pointed to "the many changes - the historical events and warlords: first the Chinese, then the French, next the Americans, and then the Soviets, [but] now we are back to Vietnamese development", which all have formed his country's national history and thus inflicted educational laws and the curriculum.

On this matter Grundtvig $(1848)^{29}$ was very outspoken, so I cited this version to them:

"If we have genuine Danish laws, / Danish schools, brand new, Danish thoughts, Danish ploughs, / Our old repute will thrive again: The Dane, prosperously endowed, / Shall live with peace and contentment upon the sea, ${ }^{, 30}$

He had no doubt that politics and education are closely related and will lead to peaceful prosperous commerce at sea instead of warfare, if all the inhabitants of a country are truly enlightened.

As for the 'poetical aspects' the students argued that "folk songs [are] related to agriculture, they lead to education in agriculture (...) the songs were created by farmers [and] they went [further] into society". So, the songs were created partly to describe the everyday life and partly to educate in the way that Grundtvig, too, suggests. He intended his own songs, hymns and psalms to serve that purpose and pointed to "merry songs" as one way of making learning joyful: "Enlightenment shall be our delight." 31

On the topic of the 'mother-tongue', they commented that it is " $a$ tool of education (...) [in] 1956 Sri Lanka 32 changed to a national language from the ethnic language - Urdu language - [and the result was] war in 1972". This was revealed to find its counterpart in Vietnam, in Laos, and in Cambodia with the French language versus the national language, the ethnic minorities' languages, and now the demand of English as the first foreign language to be learnt. In Vietnam, Russian equally played a role in the time before the Doi Moi [New Beginning], as reported in one 
student's final assignment. And, remarkable enough, Vietnamese played a role in Cambodia during the occupation of this latter country by Vietnam.

One student from Kyrgyzstan, pointed to "the Russian letters (...) that we had to learn [in the Soviet period] (...) for general language one language [is necessary] (...) [but] we speak Kyrgese, Russian, English, and Turkish [today]".

Thus inspired, one student from Indonesia recalled that "[our] local language [is] Javanese [but in] Muslim schools they learn Arabic (...) [we also learn] from French and other [languages], [so there is] no standard for translation".

Obviously, she meant that words are invented in the national language from English, Russian or French. This is, however, the way languages are built, but of course the feeling about the process is delicate when the 'borrowed words' stem from a colonial power or occupational power, so to speak. This is similar to the situation in Denmark at Grundtvig's time with German and French and Latin as symbols of elitist power.

One student from Cambodia mentioned that "[In my language] 'witchio' means 'radio"', and he told a funny example that when one day he said 'witchio' when he talked to his friend in Khmer, his friend had asked: "Why do you say that, why don't you speak Khmer?" [meaning: say 'radio', which is a borrowed word], so this friend had already forgotten, or maybe never known, the original Khmer word.

We concluded in emphasising that "it is a people's 'linguistic right' to be educated in their own language".

The 'living word' the students would understand as "a teaching method (...) reflective of the world to-day".

Some other students put it that "the folk songs are not finished (...) they tell of the life of the local people (...) They are related to participation (...) [and] background".

These suggestions show that, according to the students, the living word was capable of stimulating the participant to reflect upon the past, the present moment and the future - which comes close to the way that Grundtvig intended it, and how it unfolded in his own teaching situations.

Concerning 'folkelig', the students found it to be "something physical". They thought of it as having something to do with both appearances and ways of speaking and responding to other people.

Next, we listened to the way in which Grundtvig (1848) was intrigued by this expression: 
'Folk' [Danish for 'people']! What is a 'folk' after all? / What does 'folkelig' mean?

Is it from the nose or the mouth / That this entity is seen?

Is the 'folk' hidden to every man's eye / Only in barrows to be found Or behind each bush and plough, / In each meat lump, coarse and stout? ${ }^{33}$

From the following verse we may learn that Grundtvig thought the 'folkelige' to be something spiritual, as he calls upon the spirit of the individual people, 'Folkeaander', he names them; he encourages them to wake up and to put all things to the challenge. I interpret this as meaning that Grundtvig believed each 'folk' has its unique character or spirit connected to ways of thinking and feeling and also tied to their language, the 'mother tongue'.

So, the student's comment, like our following question, seemed to be in line with this Grundtvig inquiry: "How do we identify ourselves?" In analogy, one might ask from where our identity stems: is it a product of our time, or do history and our ancestors play a decisive role? What about language and religion: Is there a creative power in these concepts?

One student from Cambodia stated his opinion on the matter as: "By our language, Khmer (...) by our culture, we miss our country when we are away." To this my colleague made the following reflection-worthy comment: "America is foreign to me - I grew up in the Marshall Islands (...) I have had to define my own culture inside me in this world." This again made me refer to the term 'expatriate', which is the official designation of persons sent out by development agencies, and how at times this word would make me feel a little forlorn. So, not only language, but also choice of words is important to our self-perception.

'Life enlightenment' was discussed next. The students responded unanimously: "Objectives of education." An Indonesian student elaborated by suggesting that life enlightenment could be: " $A$ gender issue. For example, in 1900, in Indonesia, a woman married a Dutch governor. He made her study women's rights activities, and she initiated women's rights in Indonesia." So we concluded that something good may also come from colonisation and become part of a country's culture.

My colleague contributed the information that in eighteenth-century America women were not allowed to go to school, and the students told us that in their countries more boys than girls continue in high school or 
university even today.

My outspoken reaction was that in the gender balance of our course we might note that four women to eleven men were participating, so we still have a long way to go as far as gender balance is concerned (even though the AIT houses a Gender Studies and Development Program).

Therefore, instead of talking about national, religious or gender rights, we should perhaps talk about what it means to belong to a people, as Grundtvig does in his song of the 'folkelige':

To one 'folk' they all belong / Who themselves do reckon so / who have an ear for the mother tongue / and fervour for their fatherland." ('Folkeligheden' in Danskeren (1848), No. 24).

Grundtvig salutes women in the same song in a proclamation of what is 'truly Danish':

Neither in the battlefield nor in Parliament / children and women are disdained / whatever may go up and down / Danish is always love.

The word 'love' is intimately bound up with Grundtvig's faith in Jesus' demand that we shall love one another as He has loved us: unconditionally. In recent years this issue has been discussed in terms of human rights and has been seen as the core value in educational theory (e. g. Tønnessen 1990). ${ }^{34}$

According to Tønnessen, this debate has however provoked a caveat from legal experts since the Human Rights Declaration is a concept which is culturally influenced by religions and politics, and hence open to interpretation.

The ambiguity may seem apparent in the statement by Yamani at the first UN- Muslim conference that "human rights are a duty under Islam, but a right for Westerners". ${ }^{35}$ Again, there are differences among the "Westerners", depending on their life orientation; in Christianity this 'right' is a demand to be observed of each individual towards her or his fellow humans, not a right any one person can claim.

It only remains here to recall the students' understanding of the idea of 'interaction' or, 'living interaction', which they saw exemplified in the way in which we had all been contributing to the discussion on Grundtvig's educational idea on the background of his special religious attitude to education and faith.

In evaluating our course, the students made the following concluding statement: "This course is much more than a course, it is experience." 
Naturally, one may argue that the above associations contributed by the students could have been, and should have been, further elaborated and debated. However, be they merely associations, still they are indicators of these students' spontaneous response to us based on their immediate reflections. The duration of this double session was a limiting factor to in depth philosophical reflections in the classroom. My further reflections on this session are offered, in all modesty, in the following discussion.

\section{Further reflections on Grundtvig and the Southeast Asian Dialogues}

"but can all that bursts be mended / with the new still to be nascent?",36

\section{The courses in general}

One way to enter into a discussion of the present classroom dialogues and reflections may be by comparing them to development projects. Such projects have as their objective to create transformation, a change for the better within society to the advantage of its members.

In the case of the CLET curriculum development course the question of the students' educational background was presented to the class through the initial assignment on 'situational description and analysis'.

The assignments disclosed the different educational systems which had been prevailing in the individual countries, such as 'the Chinese', 'the French', 'the Russian' and the 'American' or 'English', including the foreign languages entailed by these systems. This was predominantly the case of the Laotian, Cambodian and Vietnamese students. Additionally, the Cambodian students could report on Vietnamese as the language of instruction during a certain period.

For the Thai students, the British educational system had been established long since and is still valid, albeit the language of instruction was always Thai, the national language, although this is not the mother tongue of the ethnic minorities. To all the students English is nowadays the foreign language to be acquired, as kind of a lingua franca.

Another condition shared among the students is the implementation of the curriculum from above, 'the top-down mode' as it was phrased, and the tradition of learning by rote and 'one-way communication', including their conception of the teacher as the 'knower' who has got all the true answers. Here we may compare with Grundtvig's view, stated in his Nordens Mytologi [Norse Mythology] that 
Man is no monkey destined in the first place to copy the other animals, and thereafter himself, to the end of the world (...) but a divine experiment which proves how spirit and dust can penetrate each other and be revealed in a mutual divine consciousness" [my translation]).

Worth mentioning also is the mutual respect he demonstrated in addressing his students 'Mine Herrer' [Gentlemen].

The challenge to the students of this course is its discursive method requesting them to reflect on the answers and their 'truth'. The framework of the course is given by the outlined topics for discussion and the assignments outlined, while the students create the course content by their discussions in small groups and in plenary sessions, involving the teachers as facilitators and discussion partners.

The course is progressively built-up, structured by the diverse tasks, accommodating both the students' experiences from their home-countries and from their studies in the AIT, thus reflecting the everyday life of both situations as well as of the historical background of the individually and nationally constituted educational traditions.

Simultaneously, an interdisciplinary process occurred between the issues, curriculum, language and the professional disciplines of the students' fields of study.

I believe that the great challenge to students as well as teachers presented by the participatory approach of the CLET course is the demand for autonomy and self-reliance on the ground of personally chosen values. These values in terms of philosophical beliefs can be fruitfully addressed by discussing the values of the individual systems in the West and the East, thus calling for an additional knowledge, or 'learnedness', among the teachers about Asian educational thinking, to allow them to enter discussions on the grounds of the students' traditions and how these may apply to a changing world: in other words, how this may meet all the alleged universality of Grundtvig's educational ideas.

The round-table sessions would perfectly suit this purpose. Thus we can speak about a 'folkelig' dimension of the curriculum development course, beyond the participatory approach. Again this is a question of 'cultivation' and 'capability', cultivation being the clarification of values, capability, the ability to manifest those values in a particular curriculum.

\section{The teacher role}

Team teaching, learner participation, group discussions, plenary 
presentation and a discursive approach gave the teachers a special role as discussion partners and facilitators, with respect to the students as participants and peers who can meet their teachers with requests about the way they think the course should run. With regard to this we may talk about 'mutual teaching and learning', in Grundtvigian words [sand indbyrdes undervisning].

The teachers found themselves in a collegial role different from the sole-teacher situation, let alone their role as learners. This method eliminates the teacher's dominance over the students, similar to what Grundtvig's address, 'Gentlemen' signals. This does not mean that the teachers have to agree upon personal opinions, but they must have some understanding in common of educational values and methodology, such as considering the students equal discussion partners and respecting their views and answers, even when challenging them.

\section{Cultural values}

At a very early stage of the courses, language as one cultural factor of importance to the curriculum proved to represent methodology as well as values, in various aspects. Among the issues were those of learning English as Foreign Language and English for Specific Purposes, which again entailed the question of the mother tongue as part of the methodology and the values behind the acceptance of different Englishes, as well as the question of the native-English-speaking teacher as the ideal.

Beyond that goes the question of the role of foreign languages in a nation's culture, the power structure of colonialism and for example the human right to be taught in one's own language, both at home and abroad. This is the vital concern in many countries with immigrants and refugees, including second generation students from those ethnic or national minorities. In addition, one may refer to the mother tongue versus the national language in countries with different provincial languages. Another aspect of foreign language acquisition is that of 'classical education'.

So, it seems evident that language mastery is a matter of cultivation and capability.

As for Grundtvig's insistence on the mother tongue for educational purposes this may seem hard to comply with, insofar as English is the instruction medium in the AIT. However, Grundtvig only intended this to be a people's right in its own country, to oppose a foreign imposed power structure. Since communication and conversation was likewise his 
educational purpose, that can be achieved, I believe, by using one foreign language as the common vehicle for education, viewing language as the bridge over the national gaps in order to implement the value of international understanding per se.

Grundtvig suggested the rainbow as a symbol of the bridge between the worlds of the mythically expressed hopes and dreams and the 'folkelige' resources, just as he considered the learning of languages to be instrumental in gaining knowledge of and insight into foreign cultures. Given the many colours of the rainbow, a similar colourful bridge of English varieties would show the beauty of each culture it communicates in a global context. The very nature of the CLET curriculum course rendered this possible.

Religious and philosophical debates on values emerged in the courses. In one September course, political beliefs in Vietnam became apparent in terms of Marxist and socialist ideas versus liberal ideas. The former gave support to planned economy, while the latter came out in favour of the free market economy. Again, the impact of these ideas on curriculum creation in a time of transition from one system to another was to change the content, not the form, thus shifting the emphasis from manifestation to values. In the May term course it appeared that there actually exists a renewed focus on religion in Vietnam, Laos and Cambodia. In Thailand and the other countries represented in this course, religion makes up a very distinct part of the students' everyday lives. Therefore, to reflect the educational traditions that the religious and philosophical values of these countries represent, it will be appropriate to discuss the same against Grundtvig's universal ideas of education and faith.

It may now be concluded that, in relation to a holistic curriculum based on the learners' experiences, religion and philosophy are determinant to the interpretation of educational values from a universal ideology into a personal and national ideology. Likewise it may prove decisive to the implementation or manifestation of these values in a concrete cultural situation. In doing so, for instance in a multicultural classroom, the meaning of cultivation and capability is apparent. In addition I would like to point to the value of text-material from the students' culture in order to have a genuine discussion on values and their universality as well as special significance and contextual manifestation to serve the purpose of true enlightenment [sand oplysning] (in Grundtvig's words).

Since both language and religion have been disseminated and diversified, promulgated and secularized through trade, it seems relevant 
to the curriculum development case to examine market values and their educational implication as to curriculum planning. This applies whether the orientation is towards a centrally planned economy or the free market, requiring procedural, stepwise five-year plan and an open-agenda approach, respectively.

The role of the teacher as the one-way speaker, the advertiser, on the one hand, and discussion partner or facilitator, the negotiator, on the other hand, is another difference that comes to my mind as reflecting the two market systems. Characteristics of the latter system and teacher will be such as flexibility and student attentiveness, other positive features to be learned from the free-market concept.

The caveat of the student as customer metaphor has been directed at the role of the teacher as salesman and the advertising of a course in competition with other courses, i.e. with drums beating and flags flying rather than based on quality, let alone the linguistic impact on the educational phraseology and communication and hence life-style-values, personal performance and, ultimately, identity.

In conclusion, viewing CLET's Curriculum Development course in the light of Grundtvig's idea of 'cultivation' and 'capability', as related to the cultural factors, language, religion and market, and then again validating these issues within the framework of Grundtvig's concepts of the historical-poetical, mother tongue, mutual teaching and learning, and 'folkelighed', it is confirmed that CLET's course is part and parcel of the question of value bases and power structures, be they individual, institutional, national, international or global. The course opened up a discussion of these relationships, precisely in the capacity of 'cultivation' and 'capability', both of the spirit and dust, that is for the participants' mental and practical everyday life, thus serving the purpose of life enlightenment as a whole.

The educational ideas in the course readings are universal in that they point to methodology and professional effective values. When it comes to touching on personal stances and affective or even emotional human values, it became obvious that the discourse needs reflection from both Asian and Western contexts, as for example in the questions of autonomy and human rights.

So my 'deep sigh' is concerned with the lack of texts discussing Asian matters. The students' future challenge will be to search for these on their own, once they have realized this need. This is so much more important since Asian educational traditions are as multifarious as are Western.

To this end, an approach based on Grundtvig's ideas has proved to be 
of relevance.

\section{Regional dimension}

In the wake of the Asianisation discussion it seems relevant to the curriculum subject to focus the 'regional dimension', which, again, first of all, raises the question of the 'national curriculum'.

To some degree a national curriculum was also Grundtvig's concern, reflecting a particular kind of Danish nationalism that is, what he called 'universal-historisk vidskab' [universal-historical insight and knowledge]. If you do not know your own roots and history how may you be able to understand other nationalities or cultures, be empathic, so to speak?

Above I have suggested the Curriculum Development course shows a similarity to Third World development projects. Regarding development aid, Allan Bloom (1988) ${ }^{37}$ warns against value-relativity in emphasising the danger of neo-colonialism. He argues that a past generation of students have been replaced

at most by students who are interested in the political problems of Third-World countries and helping them to modernize, with due respect to their old cultures, of course. This is not learning from others but condescension and a disguised form of a new imperialism (...) It is a secularized version of doing good works (op cit. (note 37), 34).

Since the educational essence of both the CLET's and AIT's work should be conceived of as development aid in terms of human resources development and capacity building, I believe the above cultural concerns are essential to this work. They are also issues which come close to Grundtvig's idea of cultivation and capability, which may accordingly be applicable in a Southeast Asian context.

\section{Grundtvig and Southeast Asia}

"Since 1958 it has been suggested that it makes good sense to link Grundtvig with the Third World." Bernt Hansen (1996) ${ }^{38}$ makes this point in referring to Erica Simon's argumentation, that Grundtvig's ideas of national identity, or 'folkelighed' may be one pathway into an awakening against imposed foreign values, since they offer a "very adequate ready-made framework (...) for the understanding of present circumstances of the Third World in the aftermath of colonialism". 
This view builds on the assumption of a universal element in Grundtvig's thinking, transcending his particular situation. Awareness of change away from the missionaries and business community is allegedly the rationale for the "transfer of Grundtvig's ideas", as argued by Bernt Hansen. Grundtvig's view on preparation for education for life lies in raising the awareness of "belonging", the author claims, a claim which intimates with the expression used by William Savage (AIT) in his Langkawi key note session, "othered", which he made a personal concern to each participant in asking "when were you last othered?".

The universality of Grundtvig's ideas rests on his nationality, while the permanence can only be understood in a dialogue with momentaryness. Therefore, in any communication of assumed universal or genuine ideas, the question needs to be addressed, whether the educational aspect and aim in itself is independent of any institutional mission statements, they may so easily become dogmas.

Curriculum creation serves a legitimate purpose in itself, namely, as Bernt Hansen formulates it (op.cit., note 38),

to make [a people] aware of what it means to be a human being at a particular point in history, with [that people's] myths, language and cultural traditions, and with the ability to utilize their resources and take their destiny in their own hands.

Grundtvig himself made the distinction between the "human life on the whole" and the "folk-life at the moment" which may be interpreted into curriculum core values and their manifestation, respectively, i.e. a matter of cultivation and capability.

The session of Grundtvig's ideas and Danish educational traditions fitted well into the context of CLET's Curriculum Development course and the round-table discussions, reflecting them so as to constitute "Life Enlightenment".

Is it, however, possible to exclude education, founded on anticipated universalities, from the "civilizing-measures" in Bernt Hansen's words, referring to Livingstone, and from "development in societies and nations which in the post-colonial period have 'development' as the keynote of their entire political approach?". This question arises from Grundtvig's attitude to missionary activities in his time, an attitude that relies on his stance "Man first, then (and thus) a Christian".

In connection with this Grundtvig stance, it must be concluded that his ideas cannot and should not be transferred as "a Grundtvigian superstructure" in Bernt Hansen's phrase, but presented for discussion in 
the actual context, as the students see it, interpreted by them into their reality. That is what we endeavoured to do by CLET's discursive and participatory approach, though we exchanged their national languages for one common foreign language, which also offered the opportunity to discuss values of words in their native languages, and translating Grundtvig's values from his native language Danish into English.

\section{Conclusion}

This is where the mutual, curricular challenge to the CLET course and to the educational field in general stands, and where the course may fruitfully apply Grundtvig's educational (and religious) ideas and positions. At the Center for Language and Educational Technology, they are facing the demand of creating a manifold curriculum together with the students in an Asian multicultural context, in the wake of democratization. The demand includes dealing with linguistic, religious and marketing concerns and also outspoken as well as subtle gender biases.

The situation described above may not be so different from possible endeavours to promote an integration of ethnic minorities in Denmark on the basis of Grundtvig's educational ideas, thus recalling his lines: ${ }^{39}$

"Truthful Heathen, Turk and Jew / Those, in essence,our Lord holds dear, / $(\mathrm{He})$ hates above all the Sweet Ones, / Who pretend to come him near."

\section{Notes}

1 Excerpts from the author's PhD thesis: Hanne L. Kjer Hansen, Uddannelsesbilleder fra Vest og Øst belyst gennem N. F. S. Grundtvigs begreb Dannelse \& Duelighed [Curriculum Composites from West and East illuminated by N. F.S. Grundtvig's Idea of Cultivation \& Capability] (Institute of Education, Philosophy and Rhetoric, University of Copenhagen, Denmark, 2000; unpublished); and the assigned public lecture 'Curriculumudvikling \& Kulturforandringer - med udblik til mulige konsekvenser for voksenundervisning i flerkulturel kontekst' [Curriculum Development and Cultural Changes - with a Perspective on Possible Consequenses for Adult Education in a Multicultural Context] (2001).

2 Steven Borish, 'From Vision to Practice: The Implications of The Scandinavian Folk Highschools for Adult Education in Today's Europe' in Thyge Winther-Jensen (ed.), Challenges to European Education: Cultural Values, National Identities, and Global Responsibilities (Frankfurt am Main, 1996), 105. 
AIT is an international university situated 42 kilometres north of Bangkok, Thailand. It was founded in 1952 by the SEATO (Southeast Asia Treaty Organization) in order to strengthen the development of the region in the aftermath of World War II. Initially it was located at the campus of Chulalongkorn University in Bangkok and intended for engineering students only. Along the years the AIT developed into a genuine university and moved to a larger campus of its own on land rented from the Thammasat University. The Danida (Danish Development Agency) sponsors a number of professorships and faculty positions at the AIT.

These terms may derive from (a) N. F. S. Grundtvig, Nordens Mytologi 'Universalhistorisk Vidskab' [Norse Mythology 'Universal-historical insight and knowledge'] (Fotografisk optryk af 3. udgave fra 1870. Samlerens Forlag, 1983), 1-39.; and from (b) N. F. S. Grundtvig, 'Om Indretningen af Sorø Academi til en folkelig Høiskole' [On the conversion of Sor Academy into a folk-university] in Finn Slumstrup mfl., Grundtvigs oplysningstanker og vor tid [Grundtvig's ideas of enlightenment and our age], (Nordisk Folkehøjskoleråd og forfatterne, 1843), 60-67.; (c) ibid., Finn Slumstrup, 'Kernebegreber i Grundtvigs oplysningstanker' [Core concepts in Grundtvig's ideas of enlightenment], 36-59. See note 4. In Folkehøjskolens Sangbog (FHS) [Songbook of the Folk Highschools]. (Odense, 1989).

7 Op.cit. ( note 4).

8 e.g. David Silverman (ed.), Qualitative Research. Theory, Method and Practice (London, 1997). Silverman relates the idea of qualitative research to ethnography, and he states three "simultaneous requirements associated with the study of human activities", they are: 1. the need for an empirical approach; 2 . the need to remain open to elements that cannot be codified at the time of the study; 3 . a concern for grounding the phenomena observed in the field (op.cit., p. 8). [my vers. From Danish]. N. F. S. Grundtvig, 'Folkeligt skal Alt nu være' [Now everything shall be 'folkeligt'] in FHS, No. 451. Asian Institute of Technology: Center for Language and Educational Technology (Bangkok, $42 \mathrm{kms}$ north).

11 N. F. S. Grundtvig: 'Nu skal det aabenbares' . [Now it shall be revealed]. in FHS No. 461.

12 In e.g. Theory of Communicative Action (1984 vol. 1; 1987 vol. 2. Boston: Beacon Press); Teorien om den kommunikative handlen-en overscettelse af uddrag (Aalborg Universitetsforlag og Institut for pædagogik og uddannelses-forskning, Danmarks Lærerhøjskole, 1997, 1996 (nu: Danmarks Pædagogiske Universitet); Jürgen Habermas, Theorie des 
kommunikativen Handelns, Bd. 1, 2 (Suhrkamp Verlag, 1981).

N. F. S. Grundtvig, 'Hvad solskin er for det sorte muld' [Like sunshine is to the black mould] in FHS, No. 146. Op.cit. (note 4 (a)).

R. S. Peters, Education and the Education of Teachers (London, 1977), Routledge and Paul Kegan. [R. S. Peters: a professor of Philosophy of Education, Institute of Education, University of London].

e.g. Robert C. Bogdan and Sari Knopp Biklen, Qualitative Research for Education (Boston, 1992), Cpt. 1, 1-58; Harry F. Wolcott, The Art of Fieldwork (Wallnut Creek; London; New Delhi, 1995).

K. E. Bugge, Padagogiske grundidéer (København).

In: e.g. Myhre, Pedagogisk Idéhistorie fra 1850 til $i$ dag [History of educational ideas] (Oslo, 1985); ibid., 'Dilthey og den åndsvitenskabelig kulturfilosofiske Pedagogikk' [Dilthey and the humanist-cultural philosophical pedagogy] in B. Bjørndal, T. Harbo and J. Haukaas (red.), Levende fortid [The living past] (Oslo).

Op.cit. (note 16).

21 Op. cit. (notes 4 and 5).

22 N. F. S. Grundtvig, 'Udrundne er de gamle Dage' [Run out have the old Days]. i FHS, Nr. 458:1

23 K. E. Bugge, Skolen for Livet. Studier over N. F. S. Grundtvig's paedagogiske tanker [The School for Life. Studies on N. F. S. Grundtvig's Educational Ideas] (1965).

Hanne L. Kjer Hansen, The Production School (special study, University of Copenhagen, unpublished, 1986).

Op.cit. (note 4 (a)), 22 (my vers.).

See note 15 .

Op.cit. (note 16).

Title page: Nordens Mytologi eller Sindbilled-Sprog. Historisk-poetisk udviklet og oplyst af Nik. Fred. Sev. Grundtvig, Praest ) [Norse Mythology or Language of Imagery. Historical-poetically elaborated and illuminated by Nik. Fred. Sev. Grundtvig, Pastor] (Anden omarbeidede Udgave, Kiøbenhavn, 1832), see. note 4. In FHS, No. 459 , v. 6.

30 In the quoted lines, Grundtvig is citing Ermoldus Nigellus' (827): characterisation of the Danes. Source: Kim A. Pedersen (personal communication, 1998); Fl. Lundgreen-Nielsen, 'Grundtvig og danskhed' [Grundtvig and patriotism] in O. Feldbæk (ed.), Dansk Identitetshistorie, 3, Folkets Danmark [The History of Danish Identity] (1992), 102 
31 N. F. S. Grundtvig, 'Er lyset for de lærde blot?' [Is the light for learned people only?].in FHS, No. 462, v. 5. (1839).

32 Former Ceylon, since 1942 a monarchy within the British Commonwealth. In 1972 the country was proclaimed a socialist republic and on that occasion the name was changed into Sri Lanka.

33 Op.cit. ( note 29).

34 Rolf Tønnessen, 'Menneskerettighetene som Verdigrunnlag i Pedagogikken' [Human Rights as Value Base in Education] in Nordisk Pedagogisk Tidsskrift, No 1. (1990).

35 Bangkok Post (11.11.98).

36 Op.cit. (note 9) [my translation].

37 Allan Bloom, The Closing of the American Mind (Penguin Books, New York, 1988).

38 Holger Bernt Hansen, 'Grundtvig and the Third World: The Transfer of Grundtvig's Ideas to Other Peoples and Cultures' in A. M. Allchin, D. Jasper, J. H. Schjørring \& K. Stevenson (eds.), Heritage and Prophecy. Grundtvig and the English speaking World (Aarhus, 299-322).

39 N. F. S. Grundtvig, 'Folket er endnu forblindet' [The people are still blinded] in FHS, No. 462 (Udvalg af Til mine to Sønner, først trykt i korrekt form 1842. [Excerpt from To my Two Sons, printed in the correct form 1842]. 